\title{
Aorto-oesophageal fistula treated with emergent thoracic endovascular repair
}

\author{
Luisa Costa Andrade, Ricardo Felix-Morais, Alfredo Gil-Agostinho, Filipe Caseiro-Alves
}

Medical Imaging Department and Faculty of Medicine, University Hospital of Coimbra, Coimbra, Portugal

\section{Correspondence to}

Dr Luisa Costa Andrade, isa.c.andrade@hotmail.com

Accepted 3 April 2014

\section{CrossMark}

To cite: Andrade LC, Felix-
Morais R, Gil-Agostinho A,
et al. BMJ Case Rep
Published online: [please
include Day Month Year]
doi:10.1136/bcr-2014-
204254

\section{DESCRIPTION}

A 85 -year-old woman was admitted to the emergency room with haematemesis and epigastric pain. The patient had a past history of diabetes mellitus and right lower limb amputation. At initial examination the patient was haemodynamically stable. Laboratory findings included a haemoglobin level of $9.6 \mathrm{~g} / \mathrm{dL}$ and platelet count of $116000 / \mathrm{mL}$. During her stay in the emergency room, the patient developed another severe episode of haematemesis and went into hypovolemic shock. Upper gastrointestinal endoscopy revealed external compression of the mid-oesophagus as well as mucosal ulceration and erosion with an adherent clot. CT angiography revealed contrast extravasation from the descending aorta into the mid-oesophagus and confirmed the aorto-oesophageal fistula due to a ruptured saccular aortic aneurysm (figure 1). ${ }^{1}{ }^{2}$ The patient underwent emergent thoracic endovascular aortic repair with deployment of a stent graft. The fistula was excluded and the patient remained stable. One month after medical discharge, the patient return to the hospital with back pain and fever. Laboratory findings revealed leucocytosis (leucocyte count of $15300 / \mathrm{mL}, 76.1 \%$ neutrophils), anaemia (haemoglobin of $8.7 \mathrm{~g} / \mathrm{dL}$ ), platelet count of $271000 / \mathrm{mL}$ and elevation of C-reactive protein $(27.63 \mathrm{mg} / \mathrm{dL})$. A repeat CT that showed the aortic prosthesis surrounded by soft tissue and gas bubbles, findings that were interpreted as peri-stent graft infection (figure 2). ${ }^{3}$ Empiric intravenous vancomycin, metronidazol and imipenem (cilastatin) was initiated after blood cultures were obtained. The blood cultures yield no growth. Despite appropriate intensive care, the patient died of sepsis 5 days after readmission.

\section{Learning points}

Aorto-oesophageal fistula is a rare cause of severe upper gastrointestinal haemorrhage and has a high mortality rate.

- Thoracic aortic aneurysm is the most common primary cause of aorto-oesophageal fistula.

- Following thoracic endovascular aortic repair (TEVAR), particularly emergent TEVAR in diabetic or immunosuppressed individuals, the patient should be closely monitored because of the risk of developing peri-graft infection. 


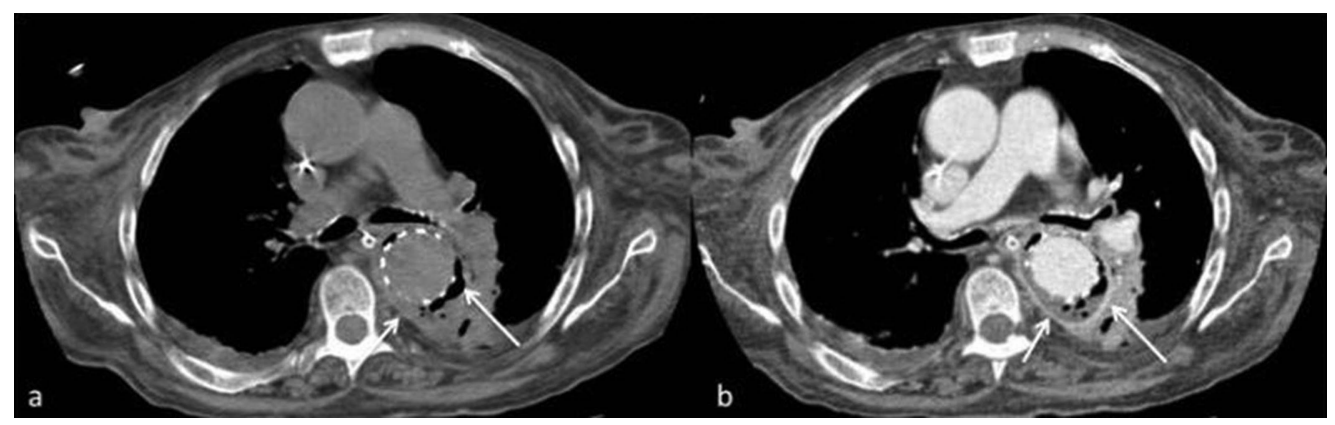

Figure 2 Unenhanced (A) and contrast-enhanced (B) axial thoracic CT images about 1 month after thoracic endovascular aortic repair show peri-graft soft tissue thickening with microbubbles of gas surrounding the aortic prosthesis (arrows) and suggesting peri-graft infection. There are no signs of endoleaks.

Acknowledgements The authors would like to thank the interventional radiology team and vascular surgeons who treated the patient.

Contributors All authors contributed significantly and equally to the drafting, writing and revising of the manuscript.

\section{Competing interests None.}

Patient consent Obtained.

Provenance and peer review Not commissioned; externally peer reviewed.

\section{REFERENCES}

1 Ishikawa N, Maruta K, Oi M, et al. Thoracic endovascular repair for aorto-esophageal fistula in patients with esophageal carcinoma: report of 3 cases. Vasc Endovascular Surg 2013;47:65-9.

2 Lai WL, Li PC, Li ML. Is it possible to treat aorto-esophageal fistula with endovascular management? Ann Thorac Cardiovasc Surg 2012;18:564-8.

3 Lee SH, Song PS, Kim WS, et al. A case of stent graft infection coupled with aorto-esophageal fistula following thoracic endovascular aortic repair in a complex patient. Korean Circ J 2012;42:366-8.

Copyright 2014 BMJ Publishing Group. All rights reserved. For permission to reuse any of this content visit http://group.bmj.com/group/rights-licensing/permissions.

BMJ Case Report Fellows may re-use this article for personal use and teaching without any further permission.

Become a Fellow of BMJ Case Reports today and you can:

- Submit as many cases as you like

- Enjoy fast sympathetic peer review and rapid publication of accepted articles

- Access all the published articles

- Re-use any of the published material for personal use and teaching without further permission

For information on Institutional Fellowships contact consortiasales@bmjgroup.com

Visit casereports.bmj.com for more articles like this and to become a Fellow 